\title{
GEOLOGICAL AND MORPHOLOGICAL EVOLUTION OF THE SOCOTRA ARCHIPELAGO (YEMEN) FROM THE BIOGEOGRAPHICAL VIEW
}

\author{
MARTIN CULEK \\ Geographical Institute, Faculty of Science, Masaryk University in Brno, Kotlářská 2, \\ 61137 Brno. Czech Republic. Email: culek@sci.muni.cz
}

Received: $28^{\text {th }}$ December 2013, Accepted: $18^{\text {th }}$ April 2014

\begin{abstract}
Some misunderstandings persist in the biological literature, concerning the geological evolution of the Socotra Archipelago. The aim of this paper is to interpret new information about the Gulf of Aden geology, from the view of possible methods of terrestrial biota species migration to the Socotra Islands. An overview of the Socotra Platform with the Socotra Archipelago topography is given. Present-day geological publications are mostly oriented towards tectonic structure of the Gulf and its tectonic evolution, and thus information concerning the elevation of the land surface and the sea level was necessary to deduce. The first biogeographically relevant emergence of a land mass in the area of present-day Socotra Archipelago commenced during the late Eocene Epoch (38-34 Ma BP). Some islands persisted after later transgressions of the sea, before the time of the opening of the Gulf of Aden rift (ca 20-17 Ma), accompanied by substantial uplift and large-scale uplift of the land. This was the last time when terrestrial biota could, relatively easily, reach the area of the Socotra Archipelago on land from the African mainland, and also with medium probability from present-day Arabia. The total evaporation of the Red Sea from 11-5 Ma BP enabled the migration of terrestrial species from and to Arabia via Somalia. Nevertheless, channels in Guardafui and Brothers basins made important, but perhaps nonfatal, barriers. The last and most important uplift of Haggier Mts. on Socotra occurred at the end of the Miocene Epoch (9-6 Ma BP). That was probably the time of the last Tertiary emergence of the Socotra Platform, potentially enabling some species to migrate across narrowed abovementioned channels. Great changes in sea level occurred during the Quaternary Period, periodically exposing the surface of the Socotra platform. Two channels persisted, preventing the invasion of modern species onto the Socotra Archipelago. Channels within the Brothers basin between Abd al-Kuri Isl. and other islands of the Archipelago formed some barriers to dispersal, and probably led to important biota differences in the scope of the Archipelago. Finally, a scenario of the "facilitation" provided by tsunami and sea currents for the immigration of biota onto the Archipelago is presented.
\end{abstract}




\section{INTRODUCTION}

The geology and biology of the Socotra Archipelago are favourite topics of scientific research in recent times, and many substantial papers were published within the last few years (Al-Wosabi \& Al-Aydrus, 2011; Bache et al., 2010; d'Acremont et al., 2005; Fournier et al., 2011; Lambeck et al., 2011; Leroy et al., 2012; Pik et al., 2013; Samuel et al., 1997). Geological history of the Archipelago, and above all the Socotra Isl., is considered to be crucial for immigration possibilities, evolution and survival of many botanic and fauna species (Brown \& Mies, 2012; Batelka, 2012). Geological research brought important information about the evolution of the Gulf of Aden (sensu lato) area, but mostly has only indirect implications for Archipelago biogeography. Moreover, such papers are written in as scientific language as possible, so it is difficult for non-geologists to understand them. Great numbers of such papers, partly contradictory in opinions, contain biologically important information concealed within extensive texts, exacerbate this problem. That is why in recent biological publications some misunderstandings of geological data are still present, or old, yet interpreted but inexact data, are presented (cf. Cheung \& DeVantier, 2006; Brown \& Mies, 2012). A recent book "Vegetation Ecology of Socotra" by later authors could demonstrate this situation well. Brown \& Mies introduce opinions of various authors on the substantial question posed by biologists: How long has the Socotra Isl. (or whole the Socotra Archipelago) been separated from Arabia and Africa. On pages 28-29 they write (slightly modified): "Krupp et al. (2002) suggested that separation of the Socotra Archipelago took place at about the same time as the separation of India and Madagascar from Africa, therefore about 165 Mya. Kopp in Wranik (1999) and Mies (2001) postulated, that Socotra finally became detached towards the end of the Cretaceous, ca 70 Mya, but other authors point to a much more recent separation."Miller \& Morris (2004) speculated on the possible existence of a recent land bridge to the Horn of Africa during the Pleistocene Epoch, when sea-levels were much lower, but Fleitmann et al. (2004) suggested that Socotra has remained isolated from the mainland for at least 15 My." Which theory is correct? All are correct, but some mentioned events are of no biogeographical importance, some have different probabilities, and when the latter is concerned, a land bridge existed but with two permanent channels. The aim of this paper is to elucidate such problems. The following text contains references to the names and character of the territory, so topography of the Socotra Platform and its surroundings has to be described first.

\section{METHODOLOGY}

Methodology is based on thorough research of geological literature, and of relevant biological and oceanographic sources. Analysis of data with respect to the terrestrial biota migration was conducted. As very little was elaborated in this respect since, almost all information was necessary to deduce. Analogy was used to characterise evolution of the Socotra Platform; analogy was searched on the southern Arabia coast, where more research was carried out (As-Saruri et al., 2010; Bache et al., 2010; Nedham, 2002). Terrain recognoscation during ecological research on the Socotra Isl. in April 2004 and in June-July 2009 was also important.

\section{Topography of the Gulf of Aden southern margin}

The Socotra Archipelago lies to the south of the Arabian Peninsula on the southern margin of the Gulf of Aden (see Fig. 1). 
Fig. 1: Position of the Socotra Archipelago on the southern margin of the Gulf of Aden. Map source: Open Street Map.

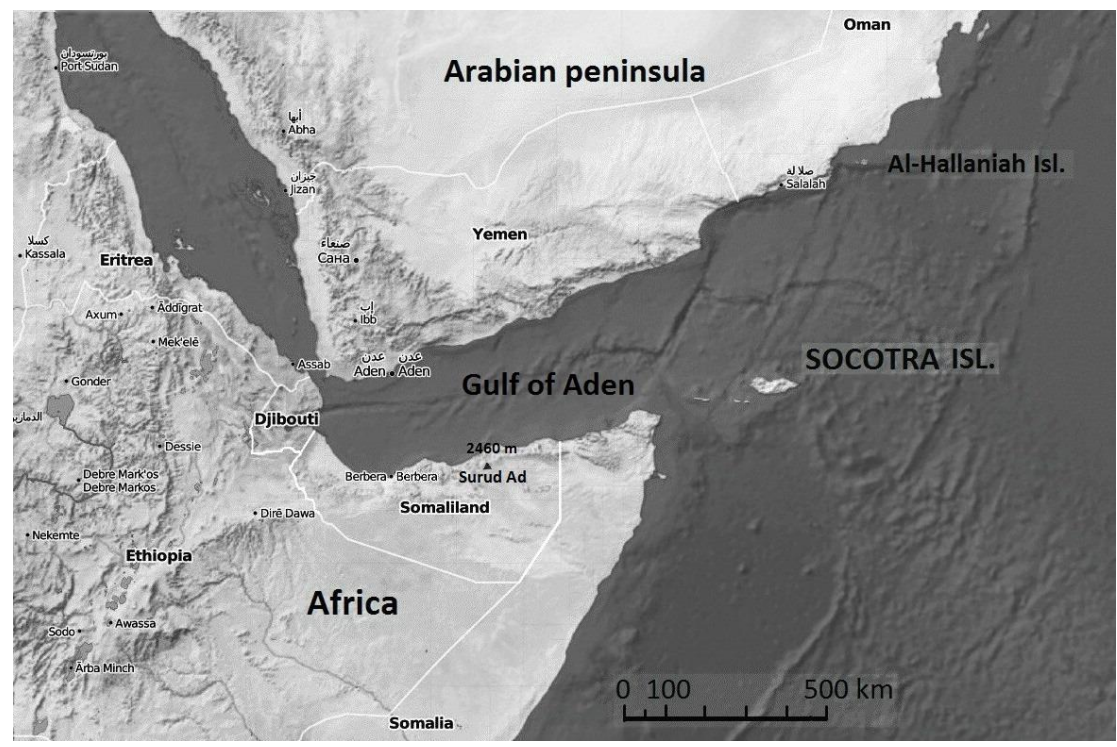

This southern margin is built in western part by tectonic uplift, and to the south-east slightly tilted Horn of Africa in present-day Somalia. The coastal ridge inclines in wave shape from Surud Ad (Shimbiris, $2460 \mathrm{~m}$ ) northwest of Ceerigaabo easterly to the Cape Guardafui. The continental shelf, nearly $60 \mathrm{~km}$ wide, continues to the east. It terminates in the Guardafui basin (graben) that is, in this section, ca $55 \mathrm{~km}$ wide. The shelf continues on the other side of the graben about $315 \mathrm{~km}$ to the east and ends ca $21 \mathrm{~km}$ to the ESE of the Ras Momi on the Socotra Isl. This extension of the Africa plate, east of the Guardafui graben, is known as the Socotra Platform (see Fig. 2).

The Socotra Platform comprises an area of about $17000 \mathrm{~km}^{2}$ and has a roughly triangular shape, with the base in east-west direction and the top of triangle to the south, about $97 \mathrm{~km}$ south of the Samhah Isl. The southern tip is in depth ca $1100 \mathrm{~m}$, too much for typical shelf, but geologically this is a tectonically subsided part of the platform (d'Acremont et al., 2005). A sea depth of $200 \mathrm{~m}$ on the platform is reached ca $60 \mathrm{~km}$ south of the abovementioned Island. The majority of the Platform is positioned at a shallow depth beneath present-day sea level, the depth being typically between 25-45 m. Some shoals south and south-west of the Samhah Isl. are reported (Anonymous, 1999b) and submarine surface in Google Earth (Anonymous, 2013) supports this information too, with shallowest points being about $10 \mathrm{~m}$ in depth. According to Google Earth maps, such places are also to be found in other locations along the Platform, interestingly often close to its rim. These places seem to be remnants of former small islands and scars, destroyed by waves. This destruction probably occurred during the Quaternary period, most likely in its later section and some of them perhaps in recent. Shallow waters and many former islands and scars make biological permeability reconstruction of the Socotra Platform extremely difficult.

The Socotra Archipelago at present consists of 4 islands and 2 scars. Total area of the archipelago is about $3700 \mathrm{~km}^{2}$, Socotra itself having an area ca $3500 \mathrm{~km}^{2}$, thus creating 95\% of the Archipelago surface. The distance from Cape Guardafui to Abd al-Kuri Isl. is $95 \mathrm{~km}$, from this island to Samhah Isl. is $64 \mathrm{~km}$, from Samhah Isl. to Darsa Isl. is $17 \mathrm{~km}$ 
and from Darsa Isl. to Socotra Isl. it is $36 \mathrm{~km}$ (see Tab. 1.). The shortest distance between Cape Guardafui and Socotra is $233 \mathrm{~km}$, but if the distance is measured in direction across these islands, it is longer $-267 \mathrm{~km}$, but only $212 \mathrm{~km}$ of it is across the sea and $55 \mathrm{~km}$ on islands. If the journey is undertaken only with use of the Abd al-Kuri Isl. and sea, it is even more favourable - only $201 \mathrm{~km}$ across sea and $36 \mathrm{~km}$ on the island, totally $237 \mathrm{~km}$. Distance between the Socotra Isl. (north of Qulansiah) and Ras Fartak in southern Yemen, the closest point on the other side of the Gulf of Aden, is $350 \mathrm{~km}$. Almost all of this course is across a deep sea.

The geology of the Socotra Platform is complex. During its long evolution this platform was cut by numerous faults of various directions, W-E to NW-SE being dominant. Southeast border of the platform is created by fault of NE-SW direction (see Fig. 2). Parallel to this, a system of faults cut off the western tip of the platform between Abd alKuri and Samhah Isl., creating so-called Brothers Basin. It is a rather narrow graben with a sill depth of about $200 \mathrm{~m}$. Brothers Basin played an important role in isolation of the Abd al-Kuri Isl. from the Samhah, Darsa and Socotra Islands. The Phoenix basin in the southeast of the Socotra Platform is a basin in geological sense; at present it is almost filled with sediments, maximum depth below the sea level being about $550 \mathrm{~m}$ in the central part of the Platform, and more than $1000 \mathrm{~m}$ on its south-east rim (Anonymous, 1999b, 2013).

Fig. 2: Socotra Platform and Guardafui basin (graben) in situation before breakup of continental crust and oceanic crust accretion (17.6 Ma BP).

Bold arrows show direction of the rift opening, and area involved in tectonic extension and faulting during rifting.

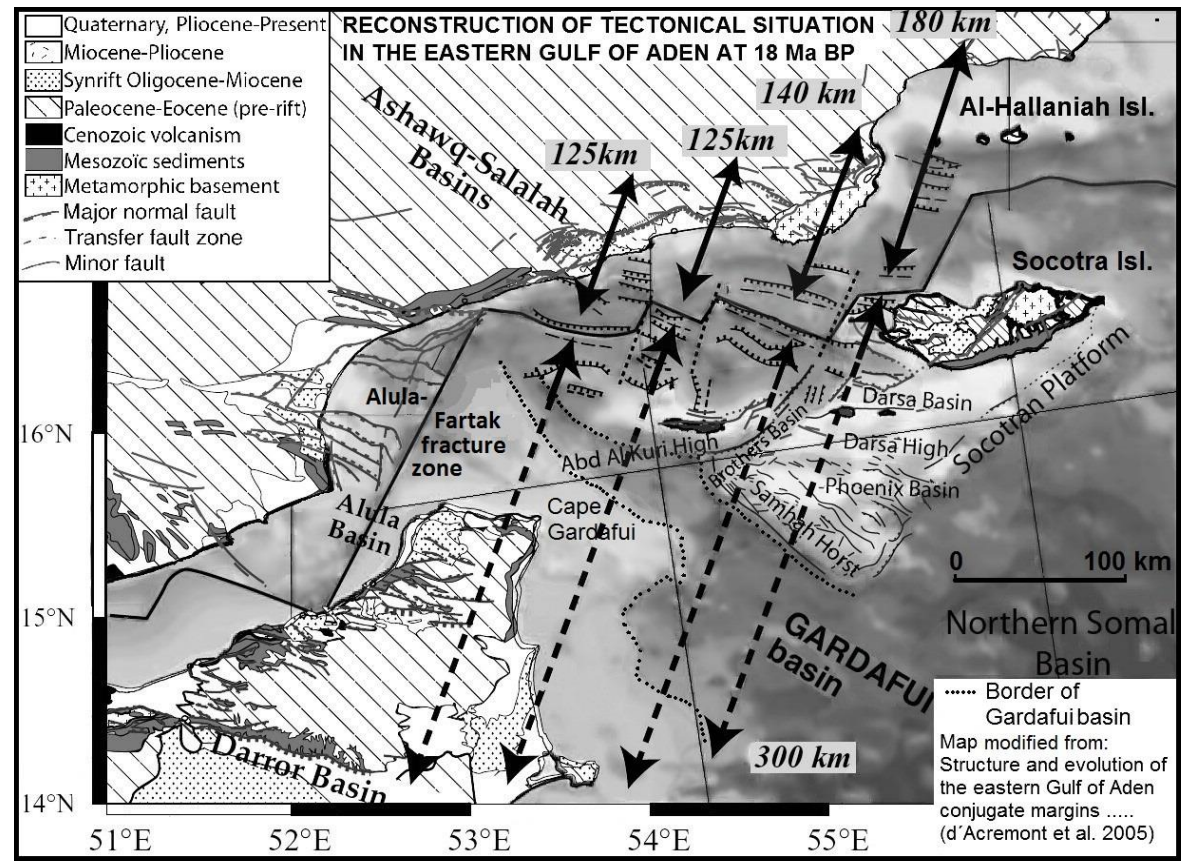

One of the most important areas under survey is the Guardafui basin (Fig. 2). It is a 290 $\mathrm{km}$ long underwater depression in the shape of a graben that stretches NW-SE between rift axis in the Gulf of Aden and Northern Somalian Basin, thus separating Cape Guardafui and 
Abd al-Kuri Island. It starts at the south-west end of Alula-Fartaq fracture zone (Bosworth et al., 2005; Leroy et al., 2013; Anonymous, 1999b, 2013) $110 \mathrm{~km}$ north of Cape Guardafui. The width of it there is ca $30 \mathrm{~km}$ and it lies at a depth of about $2100 \mathrm{~m}$. It stretches to the SE in a slightly meandering shape, cutting the Somali-Socotra shelf. The shallowest point of the bottom (the sill), is situated west of the island Abd al-Kuri, approximately $950 \mathrm{~m}$ in depth (Anonymous, 1999c, 2013). Width of the graben and its depth (meaning difference between upper rim and the bottom), increase towards the southeast. The graben terminates in the Indian Ocean, $120 \mathrm{~km}$ east from the Cape Hafun (Somalia) at a depth of about $3500 \mathrm{~m}$, as a $100 \mathrm{~km}$ wide and $3 \mathrm{~km}$ deep depression. The bottom is typically asymmetric, the deeper part being on the NE side of the graben. This basin (graben) is of ancient origin, created about $170 \mathrm{Ma} \mathrm{BP}$ in the Jurassic period. It contains ca $1 \mathrm{~km}$ of sediments, the oldest being of Jurassic age (As-Saruri et al., 2010). This graben formed a barrier to the Socotra Archipelago on several occasions during the last $40 \mathrm{Ma}$.

Topography of the Socotra Isl. was described by many authors, such as Beydoun \& Bichan (1970), Miller \& Morris (2004) or Brown \& Mies (2012). A topographical map also exists (Anonymous, 1978), and a generalised 3D relief in Google Earth (Anonymous, 2013) is visible. A generalised topographical and geological map of the Socotra Isl. is also presented in Fig. 3. An area of the Socotra Isl. is given in literature with some differences although an area approximately $3500 \mathrm{~km}^{2}$ is most probable. The western part of Socotra is slightly inclined to southeast and consists of tectonic blocks, tilted to the SSW. The highest point is on the central limestone asymmetric ridge, $878 \mathrm{~m}$ above sea level (Anonymous, 1978). About $7 \mathrm{~km}$ to the north of Ras Bedu (Baduwa), or $4.6 \mathrm{~km}$ north-west from beaches north of Qulansiah on Ras Bashuri, the depth of the sea reaches $1000 \mathrm{~m}$ (Anonymous, 1999a). Thus, almost no shelf exists on the north-western tip of the island however steep fault slopes are present. South of the Qashio village on the northern coast is the narrow part of the Island, it being only $30.5 \mathrm{~km}$ wide. The west-central zone between Ras Kattanahan and Socotra Airport, west of Hadiboh, is the lowest part of island; no ridges exceed $700 \mathrm{~m}$ a.s.l. and a watershed north of Ras Kattanahan (Kathanen) lies only ca $260 \mathrm{~m}$ above sea level (Anonymous, 1978). All depressions in the western region are tectonically derived, and in some of them marine early Miocene sediments were preserved from the erosion. Nevertheless, evolution of pediments during the late Tertiary altered them to various degrees; major re-work is typical for the Zahr basin. Eastern Socotra has features of flat limestone anticline, surrounded by escarpments. From this, close to Hadiboh transfer zone, crystalline Haggier Mts. stands out. The highest point of the Haggier Mts. is the rock tower Shaar above Homheir pass on Scant, being $1540 \mathrm{~m}$ above sea level. Southern moderate slopes of these mountains are exhumed pre-Cretaceous surfaces, from which the Cretaceous and early Tertiary limestone cover was eroded. The highest point with preserved limestone cover is on Jabal Gingimoh, located on the southern rim of Wadi Terhobeh $7.9 \mathrm{~km}$ WSW from the Shaar tower, and is $1082 \mathrm{~m}$ above sea level (Anonymous, 1978). A large oval depression (12 x $6 \mathrm{~km}$ ) east of Haggier Mts. and west of Homhil is probably not of tectonic origin, but it is a typical erosion form (pediment) from late Miocene and Pliocene; therefore no marine sediments could exist here. 
Fig. 3: Generalised topographical and geological map of the Socotra Isl.
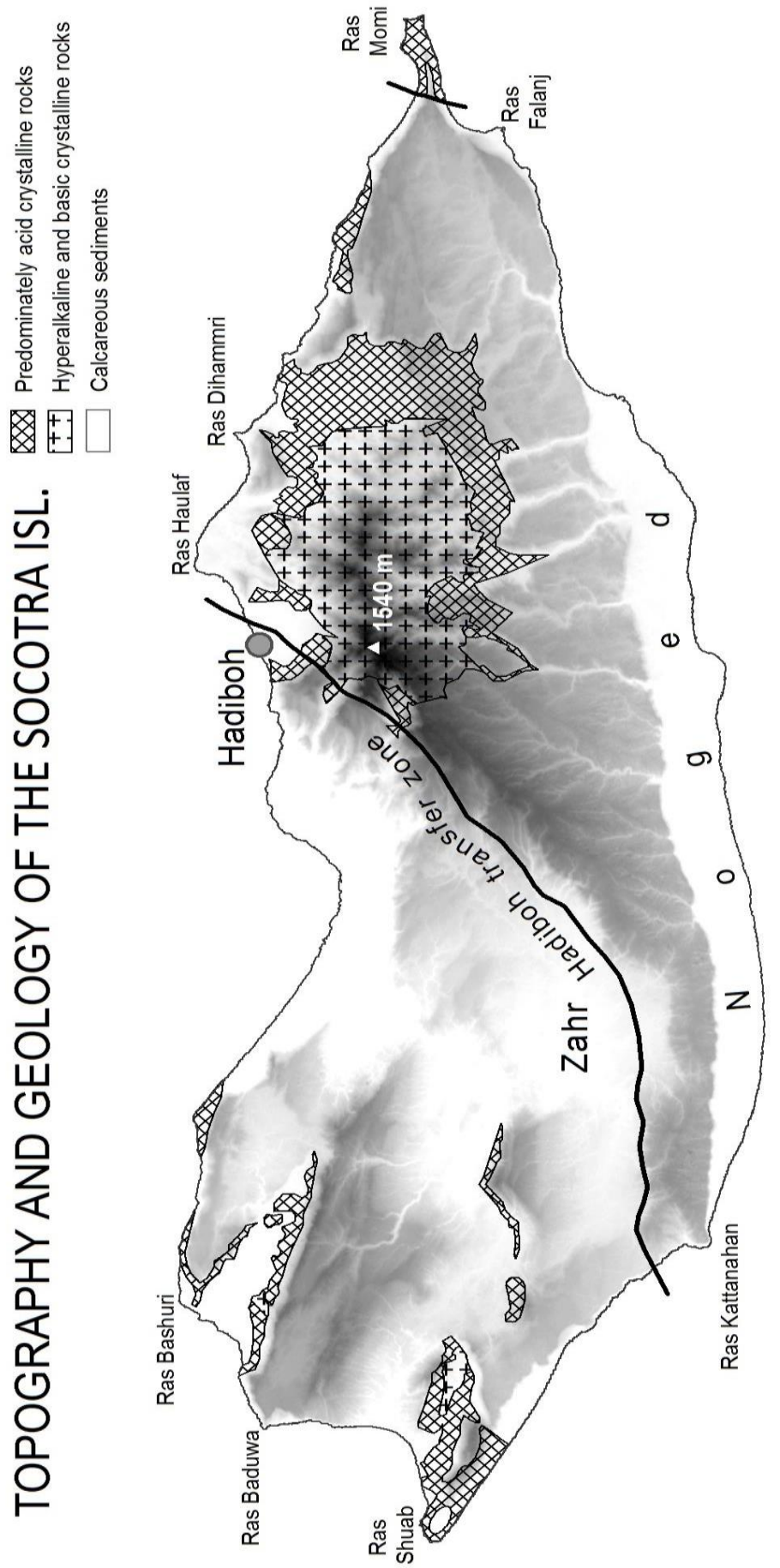

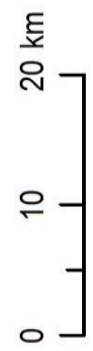

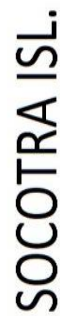

崖

능

0

㔺

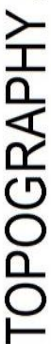

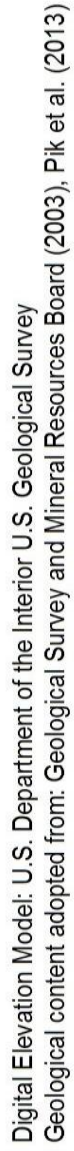


The total area of all other islands is approximately $181 \mathrm{~km}^{2}$. The Abd Al-Kuri Isl. is 36 $\mathrm{km}$ long with a maximum width of $5 \mathrm{~km}$, having an area of $133 \mathrm{~km}^{2}$ and maximum altitude of $621 \mathrm{~m}$ a.s.l. (Anonymous, 1999b). Samhah Isl. is $12 \mathrm{~km}$ long, with a maximum width of $6.8 \mathrm{~km}$ and area of $40 \mathrm{~km}^{2}$, its highest elevation being $779 \mathrm{~m}$ (ibid.). Uninhabited Darsa Isl. is $7 \mathrm{~km}$ long, maximally $2.2 \mathrm{~km}$ wide, with an area ca $8 \mathrm{~km}^{2}$, its highest point being $392 \mathrm{~m}$ above sea level (ibid.). Maximum elevations on each of these islands occur on high limestone escarpments, bedded on a crystalline basement. Scar Sabuniah is positioned 19.5 $\mathrm{km}$ north-west of Ras Shuab (western Socotra) being formed by ca $550 \mathrm{~m}$ long rock, $69 \mathrm{~m}$ high (ibid.). Scar Ka'al Firawn positioned $21.5 \mathrm{~km}$ north of western Abd Al-Kuri Isl. consists of two adjacent rock ridges, totally $1.2 \mathrm{~km}$ in length and more than $60 \mathrm{~m}$ high (Anonymous, 2013). These two scars are the last remaining examples of a feature once probably more common on the Socotra Platform.

\section{Climate of the Socotra Archipelago}

The climate of the Socotra Archipelago is tropical, semi-dry, with pronounced summer and winter monsoon periods. Due to the island's position precipitation comes during both of them, but due to its proximity to the mainland and the short distance the wind blows across the sea, the amount of precipitation is rather low (Culek et al., 2006). Transitional periods in "spring" and "autumn" are very dry and hot, especially the longer and warmer spring one. Maximal year temperatures are reached in the beginning of May (ibid.). Average annual temperature on the coast is approximately $30{ }^{\circ} \mathrm{C}$ and rainfall, depending on location, is 67-400 mm (Scholte \& De Geest, 2010). Temperatures decrease with altitude, the average temperature difference between the coast and summit of Haggier Mts. is predicted at ca $13{ }^{\circ} \mathrm{C}$. Absolute minimum temperature at the peaks of Haggier Mts. decreases to $0{ }^{\circ} \mathrm{C}$, whilst precipitation is predicted to be ca $800 \mathrm{~mm}$. However, above ca $700 \mathrm{~m}$ altitude another significant amount of water is derived from fog, probably up to $400 \mathrm{~mm}$ (Mies, 2001).

\section{Biogeographical features of the Archipelago}

According to the IUCN former biogeographical division of the world (Udvardy, 1975) the Socotra Archipelago lies in the Africotropical Realm, in its Somalian province. According to a more recent version (Olson et al. 2001), it is part of the Afrotropical Realm, Deserts and Xeric Shrublands biome. A.L. Takhtajan (Takhtajan et al., 1986) presented in his book 'Floristic Regions of the World' the Socotra Archipelago as a part of the Paleotropical Kingdom, Sudano-Zambezian Region, province No. 75 Socotra.

The Socotra Archipelago is characterised by many relicts and ca 700 endemic species of flora and fauna, and 5 endemic species of hard corals out of the 230 corals present on the Archipelago. In total, 307 out of the 825 (37\%) plant species on Socotra are endemic (Miller \& Morris, 2004). That is why the Archipelago is the world's tenth richest island group for endemic plant species. Contrary to this, no native amphibian species and no native mammal species, except bats, are present here. Surprisingly, the Archipelago hosts 7 endemic species of birds, supporting the theory of a long period of strong isolation. More than $90 \%$ of reptile species are endemic and more than 600 species of insects have been identified, $90 \%$ of them being endemic (ibid.).

Flora species have strong relationships with Somalia and Arabia; the flag-ship species Dracaena cinnabari is a tertiary relict, with related species in south Arabia, NE Africa and on the Canary Islands. Flowering plants like that of genus Kalanchoe and Helichrysum have strong links with South Africa. The genus Thamnosma (with T. socotrana on Socotra) is related to species in S. Arabia, SW Africa and SW North America. Fauna species 
composition resembles that of the African mainland (part of Afrotropical Realm), but some insect species represent links to the Palearctic. It is possible to conclude that the biota of the Socotra Archipelago is more closely linked with Africa than Arabia, but has interesting affinities with other island groups including Madagascar and the granitic Seychelles and also with remote islands within the Atlantic Ocean (Miller \& Morris, 2004).

\section{Geological history of the Socotra Platform during the period 900-43 Ma BP}

The aim of this chapter is to shortly characterise older geologic history; it is mostly of low relevance for Cenozoic (Tertiary and Quaternary) biota immigration and evolution on the Socotra Archipelago. Nevertheless, it is important for understanding the geological situation and evolution within the Cenozoic period.

The crystalline basement of the Socotra archipelago was created by intrusion of mainly highly potassic calk-alkaline pink granites and gabbro, which at present form the Haggier Mts. These rocks bear basic ecotopes (see fig. 3). In its eastern and northern surroundings and in bottoms of depressions in the far west of Socotra, outcrops comprising relatively acid granites exist (Anonymous, 2003; Denele et al., 2012). Plutonic rocks are in contact with metamorphic rocks - amphibolites, muscovite-biotitic schists and gneisses. Their age had not been ascertained yet. They outcrop on the eastern flanks of the Haggier Mts., as well as near Ras Shuab and Qulansiah to the west. Amphibolites bear slightly basic ecotopes, schists and gneiss acid variants. To the south and east of the granitoides pluton outcrop hard acid rocks of ancient volcanic origin (andesite-rhyolite), typically in the Esgego canyon. All abovementioned rocks evolved at a depth approximately $15 \mathrm{~km}$ in the Earth's crust. They were dated between 840 and 780 Ma BP (Denele et al., 2012), to the Cryogenian period of the Neoproterozoic era. It experienced rapid post-orogenetic exhumation (Avigad \& Gvirtzman, 2009). Exhumation transferred deeply buried granitoides to the upper part of the crust (at depth $<5-6 \mathrm{~km}$ ) at the end of the Neoproterozoic (Pik et al., 2013), about 600 Ma BP. Accretion of Hadiboh phyllites and low-grade metamorphosed tuffs probably occurred during the Early Paleozoic Orogeny. These series outcrops are found at some locations on margins of the Hadiboh lowland. These rocks are not hard and bear acid ecotopes.

Area of the Socotra Archipelago was exposed to subaeric erosion and denudation during a major part of the Paleozoic, causing the crystalline basement to appear at the Earth's surface before the Permian period. The borehole (Siebens Samah-1A), drilled on a horst (tectonically elevated ridge) south of the Samhah Is. (Nedham, 2002) penetrated to a depth of $2.5 \mathrm{~km}$; through $152 \mathrm{~m}$ of granite wash with some dolomite stringers (continental sandstone), from the late Permian (ca 270-255 Ma BP). It was overlying pink granite of the basement (ibid.), suggesting granite at that time was on the Earth's surface. These sediments has not been found yet on the Socotra Archipelago outcrops. The rifting between the Afro-Arabian and Laurasian plates north-east of the present Socotra platform during the early Devonian period (419-393 Ma BP) had created faults of NW-SE direction (d'Acremont et al., 2005). These faults in the Mesozoic gave rise to the Guardafui graben, later a crucial barrier for biota migration to the Socotra Archipelago.

From the late Permian period (255 Ma BP) until now, the area of present-day Socotra platform has been situated on the eastern margin of continents - first on the supercontinent Pangaea, after its breakup at the beginning of Mesozoic on the margin of the supercontinent Gondwana, and subsequently after its breakup in the mid-Mesozoic on the eastern margin of the Africa-Arabica plate (Blakey, 2011). It was mostly submerged in shallow subtropical and tropical seas, with sedimentation of limestone and eventually of sandstones or marls. 
The abovementioned Permian continental sediments in Siebens Samah-1A borehole are covered by $125 \mathrm{~m}$ of Triassic marine sandstone and dolomite marls, representing the oldest known transgression of a sea to present-day Socotra platform (Birse et al., 1997). These layers were later tectonically uplifted ca $2.5 \mathrm{~km}$ and now they are exposed in the escarpments of the eastern margin of Socotra, in surroundings of the Ras Falanj - Ras Momi (Samuel et al., 1997). Triassic basal sandstones change gradationally in limestone and marls and then up into a variety of purer carbonate sediments. Their total thickness exceeded $500 \mathrm{~m}$ (Pik et al., 2013), while only $200 \mathrm{~m}$ remained (Al-Wosabi \& Wasel, 2011). Their age was estimated to be 250-228 Ma BP. Basal sandstones vary from moderately acid to moderately basic, while all other rocks bear basic ecotopes. After this event the majority of the area was uplifted for about $40 \mathrm{Ma}$ (Al-Wosabi \& Al-Aydrus, 2011), eroded and denuded by an average of about $300 \mathrm{~m}$. Some basins evolving on subsiding blocks on the Socotra Platform enabled preservation of Permian-Triassic sediments. It ascertains tectonic breakup of the fundament and ancient faulting.

At the end of the Triassic, about $200 \mathrm{Ma}$ BP (Pik et al., 2013), basement exhumation was triggered along multiple rift margin fault systems in East Africa (Karoo event). Lavas and volcanic tuff (of $22 \mathrm{~m}$ thickness) are likely derived from this event. They were penetrated in Siebens Samah-1A borehole in a depth of about $2.3 \mathrm{~km}$ (Nedham, 2002; As-Saruri et al., 2010). They are not known to be preserved on the Earth's surface.

Sediments from the Jurassic period are known on the Socotra platform from basal beds of Guardafui graben, the Phoenix basin and eastern Socotra. Samuel et al. (1997) and at present Al-Wosabi \& Al-Aydrus (2011) dated this beginning of sedimentation on the Socotra Isl. to the early Jurassic Pleinsbachian age (about $185 \mathrm{Ma}$ BP). Dolomitic limestone of Shuqra Formation is bedded on the base. They are overlain by marine conglomerates and sandstones of the Kuhlan Formation, not exceeding $100 \mathrm{~m}$ thickness. They bear mostly basic ecotopes. To the top Kuhlan Formation outreach to the massive shallow marine carbonate sediments of the 'Amran Group. These sediments are exposed overlaying the Triassic limestone on south eastern Socotra with slight angular unconformity, showing some tectonic movements accompanied with uplift, emerging and thus hiat in sedimentation. They are also present in Guardafui graben and Phoenix basin on the Socotra platform, but were absent in Siebens Samah-1A borehole (Nedham, 2002; As-Saruri et al., 2010). Later differentiated vertical movements of the tectonic blocks and erosion of the uplifted ones is a probable cause.

At about $150 \mathrm{Ma}$ BP the breakup of the ancient supercontinent Gondwana commenced, and the North Somalian basin (present Indian Ocean) was opened with drift of the Seychelles-Madagascar-India block from the Africa-Arabia one. A rift trench simultaneously created the south-eastern slope of the Socotra platform. A tectonic sub-plate that was separated from the Socotra Platform is now present in western India. At that time the study area, situated on the eastern margin of Afro-Arabian tectonic plate, migrated across the Equator from the southern Hemisphere (Blakey, 2011). The Gulf of Aden area was topographically elevated during this period, dominantly in the western part. During rifting, eastern area of the Africa-Arabia plate suffered major tectonic dissection (faulting) in direction of NE-SW. One of these faults would later create crucial discontinuity in evolving Socotra Island - the Hadiboh transfer fracture zone (see fig. 3 and next paragraph). A series of long basins, orientated NW-SE to WNW-ESE, dissected the eastern part of Africa-Arabica plate, i.e. present-day Somalia, the Socotra platform and southern Arabia. They were gradually subsiding, thus preserving abovementioned Triassic and Jurassic sediments. At present these basins have their parts on both African and Arabian 
plates, cut by more recent Gulf of Aden rift. The Guardafui graben and Phoenix basin are the biggest ones in the area under study.

The Socotra Platform and its surroundings were highly dissected to small tectonic unities at that time, having substantial influence on the evolution and biota colonisation during the Tertiary period, due to uplifts and subsidence of some of them. On Socotra Island itself, there is evidence of transfer structure located on east on Ras Momi (Leroy et al., 2012) with uplift and eastward motion of the basement on this cape. Socotra platform sediments on emerged blocks were substantially eroded, sometimes as deep as the Neoproterozoic crystalline basement. That was also the case of Socotra Island, with abovementioned exception of east escarpments, where these are preserved. Thus the opinion of Krupp et al. presented in the book Vegetation Ecology of Socotra (Brown \& Mies, 2012), that Socotra was separated from Africa about that time, is true only in a tectonic sense - the platform was cut by faults and some basins started to subside. As the whole area was submerged several times in the future, this "separation" was almost of no importance at that time.

Nevertheless, the sedimentation of shallow marine limestone and shale periodically continued in basins during the early Cretaceous (As-Saruri et al., 2010). These rocks are presented first of all on western islands of the Socotra Archipelago. Great changes occurred at the beginning of late Cretaceous, starting with the Cenomanian age (100 Ma BP), when large sea transgressions commenced on the Socotra Platform. On the Socotra Isl. during ca $33 \mathrm{Ma}$, more than $400 \mathrm{~m}$ of basal sandstone, limestone, partly interbedded with shale and sandy shale, covered older rocks (sediments or crystalline basement). In subsiding basins of the Socotra Platform thickness of these sediments exceeds $700 \mathrm{~m}$. Total amount of Cretaceous sediments penetrated by Siebens Samah-1A borehole reaches $1334 \mathrm{~m}$ (Nedham, 2002). Basal sandstones are of slight basic character, and other rocks bear basic ecotopes.

Uplift and regression of the sea occurred at the end of the Cretaceous, at about $67 \mathrm{Ma} \mathrm{BP}$, probably in the whole area (without exception of basins!), lasting until the early Tertiary, ca 59 Ma BP (As-Saruri et al., 2010). Large-scale erosion and denudation lowered the surface at minimum ca $100 \mathrm{~m}$, and on some more elevated tectonic blocks probably more substantially. On the Socotra Isl. the thickness of Cretaceous sediments is about $1 \mathrm{~km}$ less in comparison with the abovementioned borehole that means the denudation reached ca $1000 \mathrm{~m}$. On the Ras Shuab on western Socotra, Tertiary sediments directly overlay crystalline basement; this suggests that denudation was so deep, that Mesozoic sediments were totally eroded. This is in coincidence with an opinion of Brown \& Mies (2012), that some parts of present-day Socotra were elevated at that time. On the other hand, there is no evidence that the basement of Haggier Mts. was also exhumed at that time. This is of no biogeographical relevance anyway, as the entire area was probably later submerged. In Tertiary sediments on its present slopes there are no ascertained signs of permanent emergence of the Haggier Mts.

Transgression with marine sedimentation commenced during the Tertiary period, ca $59 \mathrm{Ma} \mathrm{BP}$, and lasted until the late Eocene, ca 38 Ma BP (As-Saruri et al., 2010). The striatic sequence of limestone with thin marl beds, more than $1 \mathrm{~km}$ thick, covered all older rocks in vast areas of eastern Africa-Arabica, i.e. also on the Socotra platform. All of these sediments were deposited in shallow marine waters 5-10 m deep, mostly in contact with coral reefs and some low flat elevations above sea level (Al-Wosabi \& Al-Aydrus, 2011). These small islands and lagoons were probably short-lived, but in various places evolving and disappearing. During sedimentation of the Rus Formation (ca $50 \mathrm{Ma}$ BP) some dry-out flat basins with evaporites were also present in the area. This is the first time since some patches of emerged land could persist to present time within the broad surroundings of present-day Socotra Isl. The probability of this is low anyway. 


\section{Younger geological history of the Socotra Platform (43.0-5.3 Ma BP)}

During this period, geological evolution of the whole territory had a direct impact on the terrestrial biota immigration to Socotra Archipelago, and on the local evolution, whereby the consequence of tectonic movements had been most important.

In the complex of Tertiary sediments there is a strange $2.5 \mathrm{~m}$ thick layer of sandy limestone in Damman Formation, dated approximately 43 Ma. It contains medium sized grains of quartz with sharp edges, supporting the idea of very short transport (Al-Wosabi \& Al-Aydrus, 2011). Their only source could be crystalline rocks of old Socotra basement. Presence of quartz grains refers to an exhumation of the basement, but according to present knowledge, it should be covered at least by hundreds of metres of Cretaceous and Tertiary limestone. The layer was discovered on the slopes of Jabal Haiybah, east of the Qadub village above the road between Socotra Airport and Hadiboh. It is situated less than $5 \mathrm{~km}$ west of closest outcrops of crystalline rocks. In a comprehensive recent study (Leroy et al. 2013), some short period of pre-rift movements is supposed about that time. Perhaps some small tectonic block was uplifted by faults of the future Hadiboh transfer zone to the surface (ca $43 \mathrm{Ma}$ BP). This means that the larger part of the surface had been elevated to higher position and emerged, so that erosion as far as the basement was possible - that requires relatively high island (some kilometres in diameter and few hundred meters in altitude by estimate). Whether the island could persist until the next uplift of the whole territory is questionable, and by the author's opinion the probability is medium. But if the island was created and survived for the next ca 2-5 Ma years, it would be the very beginning of the present Socotra Isl. More recently, only shallow marine sediments bedded among flat islands, mostly of coral origin.

At the beginning of the Bartonian (41 Ma BP) a small uplift of whole area began evolution of the Gulf of Aden rift slowly commenced (As-Saruri et al., 2010; Leroy et al., 2013). This was accompanied by the sea regression and emerging of a large, flat carbonate platform. The emerged Socotra platform was an eastern extension of the Horn of Africa in Somalia, therefore the area of present-day Socotra archipelago was connected with the Africa mainland, the Guardafui graben probably being a weak barrier. The predecessor of Socotra Isl. emerged several tens of $\mathrm{km}$ south of contemporaneous Al-Hallaniah Island, south of the Oman coast (Fig. 2). North-west part of the present Socotra Isl. was situated ca $80 \mathrm{~km}$ south-east of the present-day Samhan Mts. (the Sultanate of Oman). Socotra itself was never connected to the present-day wet Dhofar coast (on the frontier between Yemen and Oman), it was positioned much more easterly. On the other hand, territory of Island Abd al-Kuri was close to western slopes of the Samhan Mts. and therefore from the present wet coast some $30 \mathrm{~km}$ to the south-east.

Permanently emerged areas since that time are highly probable, facilitating the biotic colonisation of the predecessor of the present Socotra Archipelago. The Guardafui graben was probably filled with sediments at that time, but during this late Eocene epoch it was reactivated, i.e. deepened. Whether it created a marine barrier at that time is questionable, but the existence of some narrow and shallow channels is probable. A fault of transitional Jurassic/Cretaceous age of NE-SW direction was also reactivated, cutting present-day Socotra Isl. from Ras Haulaf on the northern coast in a southerly direction, from Hadiboh to the Wadi Roukep north of Ras Qatanan (or Kattanahan) in the south-west. Due to throws and lateral movements during next periods it evolved in a ca 1-4 km wide fault zone, consisting of a system of subparallel faults. It is a very important so-called Hadiboh transfer fracture zone (see Fig. 2 and 3).

A major phase of uplift, important from a biogeographical point of view, commenced about $38 \mathrm{Ma}$ BP east of Hadiboh transfer zone. The entire eastern part of present Socotra 
was slightly tilted to the south, with a relatively steep slope evolving to the north. Strongest uplift (of about $2 \mathrm{~km}$ ) occurred at present-day Haggier Mts. This uplift lasted ca 6 Ma years (Pik et al., 2013). Extension in uplifting rift led to large contemporaneous slides of blocks of sediments to the north, to deepening rift axis. This tectonic exhumation reached 1.3-1.6 $\mathrm{km}$ and infringed even the crystalline basement (ibid.). Intense erosion supported this process. No high mountains were created, as tectonic denudation and erosion continuously flattened the elevating surface. In the western section of present Socotra Isl. the uplift started later, ca $34 \mathrm{Ma} \mathrm{BP}$, being slower and longer, ending ca $26 \mathrm{Ma} \mathrm{BP}$. Mostly low highlands were elevated there, but tectonic exhumation and erosion reached the crystalline basement at some places, especially on the far west (Pik et al., 2013). Similar local uplifts also occurred on the elevated future Socotra platform, leading to denudation of the majority of sediments and possible exhumation of the basement, minimally on the present-day Abd al-Kuri Island.

Rifting consisted of weakening of the continental crust in present Gulf of Aden and broad surroundings. Slow perpendicular extension of the flat ridge - future Gulf of Aden rift - led to subsidence of the surface in its longitudinal axis. Area of this axis submerged under shallow marine waters (Bosworth et al., 2005; Leroy et al., 2013). This is an important phase of the evolution of whole territory, also from biogeographical view, as separation from recent Arabia commenced. The basal marine sediments are of $35 \mathrm{Ma}$ age. The platform of present Socotra Archipelago slightly tilted to the NE, to the subsiding ridge axis, too. At the end of Eocene epoch (34 Ma BP) shallow water limestone sedimentation commenced at least in shallow basins in western parts of recent Socotra Isl., close to the Hadiboh transfer zone. Coral reefs formed on small elevations in the sea.

Between 34-33 Ma BP the Eastern Antarctic glacier came into existence (Barry \& Gan, 2011) and global sea level dropped quickly by approximately $50 \mathrm{~m}$. This event also supported terrestrial biota survival and migration, to an extent.

Throughout the next $\sim 8$ Ma years (until $26 \mathrm{Ma} \mathrm{BP}$ ) the sea in axis of arising Gulf of Aden was shallow and contained coral reefs, some parts drying out creating sandy plains and evaporation basins (As-Saruri et al., 2010). Occasional land bridges formed, enabling migration of terrestrial biota. This migration was also possible through the western part of present-day Gulf.

At $30 \mathrm{Ma}$ the subsidence of the surface accelerated in rift axis. Idiyu Formation bedded in western Socotra basins continues on the Socotra Platform - evidence of transgression on the shoulders of the rift. Nevertheless, the sea was shallow and coral reefs formed. Due to tectonic fragmentation of the platform, it is highly probable that some horsts and flat elevations emerged. Area of future Haggier Mts. was emerged too.

Approximately $26 \mathrm{Ma} \mathrm{BP}$, the platform in rift axis collapsed, and differential vertical tectonic movements created deepening basins, not only in the axis. Tectonic blocks of western Socotra did slide to the rift again, being submerged and tilted to the south. The same process started on the whole southern margin of opening rift. Deepwater sedimentation of turbidities (chaotic sediments of stones, marls, sands) started in submerged basins. On Socotra this is confirmed only within the western part, where marine conglomerates and sandstones are present. With consequent widening of the rift axis, shoulders of arising rift slowly subsided nevertheless some emerged parts remain on southern part of present-day Socotra Platform. It is highly probable that elevated parts of eastern Socotra, especially present-day Haggier Mts., also caused island formation. Also in nearby Somali land uplifts and drops in surface elevation of several kilometres are known. The uplift of the present Haggier Mts. during this period was only partial, and the area 
subsequently remained for millions of years mostly covered by limestone, as structure of sediments north of them shows (Pik et al., 2013). Nevertheless, possibilities for terrestrial biota migration from and to separating Arabia gradually diminished.

Approximately $24 \mathrm{Ma}$ BP the channel Bab al-Mandeb at Djibouti between Africa and Arabian Peninsula was open for the first time. The depression in present-day southern Red Sea was filled with marine water and the migration possibilities between Arabia and southern coast of the Gulf of Aden were restricted. At that time it was narrower than today (being $26 \mathrm{~km}$ at present), so for some terrestrial species this barrier was not fatal.

It is highly probable the majority of the area had undergone great transgression of late Oligocene-early Miocene ocean in 23-20 Ma BP (As-Saruri et al., 2010). On the other hand, uplift of the shoulders of the rift started, emerging some horsts. Higher erosion led to maximal speed of sedimentation in deepening basins.

Important evolutionary changes occurred $20 \mathrm{Ma} \mathrm{BP}$, when strong pull-apart of thinned continental crust started (d'Acremont et al., 2005; Fournier et al., 2011; Pik et al, 2013); this is so-called OCT phase (Ocean-Continental Transition). The area of the Gulf of Aden was uplifted and this uplift continued until 17.6 Ma BP. In that time mostly shallow marine sediments were bedded in the axis of the rift. That means some flat coral reef islands could exist, creating stepping stones for terrestrial biota migration between the southern rim of the rifted area and northern rim in Arabia. Nevertheless, deep basins persisted as well. On the other hand, melting of Antarctic glaciers and other global geological changes led to sea level elevation about $20-40 \mathrm{~m}$ above present levels. This restricted the possibilities of presence and migration of terrestrial biota to little extent. The whole area was maximally uplifted during a short period of final breakup of the continental crust, between 18-17 Ma BP. Important uplift and associated basement exhumation could be accommodated in the proximal portion of rifted margins (Pik et al., 2013). The highest position of rift shoulders (with Socotra being a part) is supposed at this moment.

About 20 Ma BP the Guardafui graben was flooded, about 18 Ma BP probably only slightly. At that time it could be tectonically some $40 \mathrm{~km}$ wide on the sill - less than today - and the channel, if it existed, was even narrower. This was the last time that species could cross it with relative ease; nevertheless, it probably did form a barrier for the majority of terrestrial biota.

As the Socotra Isl. is concerned, western and eastern parts reacted differently. The section west of Hadiboh transfer zone suffered great tilting of blocks, but only a moderate uplift. At 17.6 Ma BP the western part of Socotra had emerged completely, and the Socotra Platform had emerged too. The eastern part of the Island underwent higher uplift on average. The location of the maximum uplift was close to the Hadiboh transfer zone, in the wedge of faults in present-day Hagghier Mts. (Pik et al., 2013). That means Haggier Mts. were elevated the most, and additional denudation of $0.7-1 \mathrm{~km}$ of its rocks occurred. Nevertheless, according to preserved sedimentation cover of lower southern slopes of the Haggier Mts., the uplift could not be extreme and the mountains probably attained a height of about $1 \mathrm{~km}$ a.s.1.

At 17.6 Ma BP the accretion of oceanic basalt crust began in eastern Gulf of Aden rift. The tension in the crust slacked and slow subsidence commenced across the whole rift area. The Guardafui basin (graben) was reactivated at that time by pressure of the eastern part of the rift opening, and its bottom subsidence accelerated. The resulting basin created during this period gradually formed a wider and deeper barrier.

After this period, about $17 \mathrm{Ma}$ BP, rift shoulders with Socotra Platform and Socotra itself started to subside with progressive speed. About 16 Ma BP the altitude above sea level of lower parts of the Socotra Island was about the same as now. The subsidence then slowed 
down, nevertheless the Socotra Isl. submerged to about 100-300 m below its present position. It is confirmed only for the western part of Socotra, although it is probable for the eastern part as well. On coastal lowlands of that time marine sedimentation began in places of recent lower ridges and their slopes. Coral reefs occurred and reefal platform was created first. As a result of the next short subsidence, some sands and pebbles were bedded. A following slight uplift recovered reefs with their minimal sedimentation. This sediment beds were as Adawnib (=Ayaft) Formation of age 16.0-11.6 Ma BP described (Leroy et al. 2012 in Pik et al. 2013, Leroy et al. 2013). Almost identical sediments developed on eastern Somalia coast. No information about these sediments on the shelf of Socotra Platform was found in literature. Nevertheless, as they were bedded on both margins of the Platform - on Somalia and Socotra lowlands - it is probable that they were also present on the lower parts of the Platform. This implies that the shelf of the Socotra Platform was submerged, thus forming a significant migration barrier for terrestrial biota. This situation started at about 16.0 Ma BP and probably lasted throughout the next ca 7 Ma.

The sedimentation of Adawnib Formation was followed by Nar Formation, which on Socotra bedded in 11.6-8.0 Ma BP (Leroy et al., 2013). It was bedded in extremely shallow sea close to the coast of that time. This was the last marine sediment formation on the Socotra Isl. Contemporaneous with Nar Formation probably are the oldest alluvial sediments in basins of western Socotra. The largest outcrops of these are found within the Zahr basin, with lowest elevation dropping to ca $100 \mathrm{~m}$ a.s.l., supporting the idea that inner basins of Socotra were above the reach of marine transgression at that time.

At 14-10 Ma BP great glacial expansion within the southern Hemisphere led to led to decrease of the global sea level (Barry \& Gan, 2011). Through the channel between the Gulf of Aden and the Red Sea flew only restricted amount of water, and by 14 Ma BP the Red Sea started to dry up. At 11.6 Ma BP the global sea level was about $100 \mathrm{~m}$ lower than in previous situation. As a consequence, the abovementioned sill emerged. This resulted in total drew-up of the Red Sea, thus only evaporite sedimentation (mostly salt) on the bottom is known until 6.5 Ma BP (Bosworth et al., 2005). Before 7 Ma BP the Greenland glacier appeared, thus causing a decrease of global sea level by about $-5 \mathrm{~m}$ (Barry \& Gan, 2011). All of these factors enabled terrestrial biota migration between southern Arabia and Africa.

The cessation of marine sedimentation on Socotra Island, about $8 \mathrm{Ma} \mathrm{BP}$, was a consequence of uplift. As the majority of the Socotra Platform is concerned, the uplift was relatively small. The Socotra Platform was separated only by a channel in the Guardafui basin from the African mainland, thus strongly restricted migrations were possible here. The Brothers basin (see Fig. 2) probably subsided at ca 9 Ma BP and was submerged. It created a semi-permeable barrier between the Abd al-Kuri Island and islands of the Socotra Archipelago more to the east. Thus, Abd al-Kuri Isl. could be reached by species migration from the Africa more easily than other islands.

Until recently it was hypothesised that the Socotra Isl. was uplifted after 9 Ma BP only slightly, in accordance with the Socotra Platform. No uplift was supposed by Pik et al. (2013). Fournier et al. (2010) supposed that the anticlinal shape of Socotra (east of Hadiboh transfer zone) resulted from final uplift and break-up of the Gulf rift at 20-17,6 Ma BP. Nevertheless, two major problems exist:

1. Altitude and young morphology of the Haggier Mts. excludes old or only small uplift. The presence of Paleogene limestone at a height of almost $1.1 \mathrm{~km}$ above present sea level, 
suggests that the substantial uplift of the Haggier Mts. commenced much later than 20-17 Ma BP. Otherwise these sediments would be completely denudated ${ }^{1}$.

2. Sediments of the Adawnib Formation persisted on Socotra in small rests close to recent coast in Shouab bay, on hills south of the Socotra Airport, and major outcrop being on Haulaf Peninsula east of Hadiboh. Crucially, they are highly tilted in accordance with underlying older limestone. That is clear evidence for strong younger tectonic uplift and tilting, which commenced after 11.6 Ma BP.

The abovementioned statement suggests that uplift of some tectonic blocks on the Socotra Isl. was young and intense. Can this idea be supported further? Some arguments are indirect. During the Tortonian age (12-7 Ma) a third uplift is recorded on the northern margin of Gulf of Aden (Pik et al., 2013). At 12 Ma BP volcanic activity began in lowland basins in southern Yemen, accompanied by unconformity in sedimentation - the reef limestone sedimentation finished and continental conglomerates have been bedded up to now (As-Saruri et al., 2010). That is an indication of significant uplift. At $10 \mathrm{Ma} \mathrm{BP}$ shallow marine sedimentation occurred on the Oman coast, and about 8 Ma BP large quantities of sediment slided to the opening bottom of the Gulf of Aden, this too being a clear sign of strong uplift (Bache et al., 2010). About $8.8 \mathrm{Ma}$ BP the speed of opening of the eastern Gulf of Aden rift to the south increased substantially (Fournier et al., 2010), probably increasing pressure on this margin, potentially leading to its uplift. During the period 9-6 Ma BP the western segment of the Sheba ridge (rift ridge on the bottom of eastern Gulf of Aden) north-west of the Socotra Isl. also spread in a WNW and ESE direction (d'Acremont et al., 2010); this pressure on Socotra could be another source of its uplift.

At that time a character of oceanic crust accretion in eastern Gulf of Aden also changed a segment of oceanic floor connected with the eastern part of Socotra started to spread more rapidly, than that connected with western Socotra (Fournier et al., 2010). This could be a cause of higher uplift of the Haggier Mts. Bott et al. (1994) supposed the influence of some horizontal pressure on folding and uplifts of eastern Socotra, but Beydoun \& Bichan (1970) did not find evidence to support this, as Fournier et al. (2011) mentions. Nevertheless, increased pressure on Socotra, and especially on the eastern part, was present, as shown above. Leroy et al. (2013) also presented greater uplift of the northern part of the Socotra Platform than of the south coast of the Socotra Isl., caused by pressure from the north-east. According to these authors, this event occurred between 16-0 Ma BP, and was accompanied by tilting and uplifts of local tectonic blocks. It is possible to conclude, with high probability, that during the period 9-6(5) Ma BP the whole of Socotra was slightly uplifted; highlands were, on average, moderately uplifted, and strong uplift created present-day Haggier Mts.

\footnotetext{
1 Note: Previous important uplift occurred during OCT at 20-17.6 Ma. If this had been the last time, for instance the Haggier Mts., would have been substantially uplifted, they would be eroded to the sea level by now. Speed of the denudation of mountains depends on the tectonic intensity dissection, chemical composition of bedrocks and upon climatic factors. The speed of denudation of Hercynian Mountains (with softer bedrocks) in present-day Central Europe during the late Carboniferous (with wetter climate), was calculated to be 140-210 m/Ma (Kalvoda 2005). This figure is in good correlation with amounts presented in Encyclopedia of Geomorphology (Goudie 2006a,b), as average figure for catchment areas in recent (sub)tropics denudation is 100-200 m/Ma. As the relief of the Haggier Mts. is steep, but Climate drier, a value of $100 \mathrm{~m} / \mathrm{Ma}$ could be an adequate minimum. It is possible to conclude, that the depth of denudation after 17.6 Ma years could be close to $1.7 \mathrm{~km}$. The presence of mountains and limestone sediments attaining a height of almost $1.1 \mathrm{~km}$ above present sea level suggests, that the final and great uplift of the Haggier Mts. commenced much later.
} 
The uplift had to be quick as it probably slowed down approximately 6 Ma BP. About that time signs of a reduction in speed of all tectonic movements occurred - the speed at which the eastern Gulf of Aden opened, decreased, and only small faulting occurred (Fournier et al., 2010). Nevertheless, during the period 6-5 Ma BP stratovolcanoes were created in Yemen (Nedham, 2002), ca 5.5 Ma BP uplift in central Somalia was registered, whilst the widening of the Red Sea with oceanic crust accretion, as well as strong uplift of rift shoulders in Yemen and Eritrea, and rotation of the Arabian Peninsula, all occurred around 5.3 Ma BP (Bosworth et al., 2005). Uplift of the Oman coast lasted in 7-4.5 Ma BP, and between 4.8-3 Ma BP intense erosion of lavas in Afar was also caused by their uplift. All of these events are indicative of tectonic activity within the broad territory, and possibly some uplifts on Socotra, too. Nevertheless, it is probable that about 4.5 Ma BP vertical and horizontal movements on Socotra almost diminished, and the Socotra Platform was flooded with the exception of islands and scars. Certainly, strong erosion of highlands and mountains on the Socotra Archipelago continued.

In contrary to previous glacial expansion in Antarctica, warming of this continent between 9-6 Ma BP led to a sea level increase (Barry \& Gan, 2011), the highest occurring ca $5 \mathrm{Ma} \mathrm{BP}$. Global sea level at that time was the highest within the last $12 \mathrm{Ma}$ BP (Haq, Hardenbol \& Vail, 1987). As a consequence of partial melting of Antarctic glaciers, the channel between the Gulf of Aden and the dry-out basin in the recent Red Sea was flooded. About 6.5 Ma BP the Red Sea was recovered, and ever since has presented an important migration barrier for (sub-) tropical Africa and southern Arabia terrestrial biota.

\section{Evolution and migration possibilities in Pliocene-Quaternary period (5.3-0 Ma BP)}

Tectonic movements in the area under study woke in this last time span. The evolution of the Socotra Archipelago and of its surroundings was influenced dominantly by sea level changes, caused by evolution of glaciers in higher latitudes of the Earth (Barry \& Gan 2011; Haq et al., 1987; Lambeck et al., 2011).

During the Pliocene Epoch great changes in polar glaciations commenced (Barry \& Gan, 2011). During the period 5-3 Ma BP the West Antarctic glacier broke up on several occasions, and also the shelf glacier in the Ross Sea melted. At 3.5-2.73 Ma BP the widespread permanent glaciation of the Northern Hemisphere occurred. Expansion of glaciers within the Southern Hemisphere occurred during the period 3.3-2.4 Ma BP; significant glaciation in Antarctica started at $3 \mathrm{Ma} \mathrm{BP}$, and the extent of glaciers in Antarctica was comparable to that of glacial periods during the Pleistocene (ibid.). This suggests the sea level decreased by about $-70 \mathrm{~m}$. As no more substantial tectonic uplifts and drops changed the position of the Socotra platform, this decrease in sea level probably led to the emergence of its majority. Thus by about 3 Ma BP migration possibilities for terrestrial biota, between the Socotra Archipelago and Africa mainland, periodically increased again. Nevertheless, the Guardafui basin was fully flooded, as was the Brothers basin, creating substantial barrier.

Changes occurred at the beginning of the Quaternary period. It started at 2.56 Ma BP with the first strong glaciation of the northern Hemisphere, with repeated creation of thee Greenland ice sheet (Barry \& Gan, 2011), which caused another decrease in sea level (about $-5 \mathrm{~m}$ ). Nevertheless, during the older Pleistocene period the sub-polar latitudes of the Northern Hemisphere were warmer than in more recent times. Contrary to this, at 2.4 Ma BP strong cooling led to drop of the sea level about $110 \mathrm{~m}$ lower than presentday, thus enabling biota migrations across the former submerged shelf. Contradictory changes in extent of glaciers were typical in next periods too; for instance, during an interglacial period about $1.07 \mathrm{Ma}$ the West Antarctic glacier broke up completely 
(Barry \& Gan, 2011). The number of Quaternary interglacial-glacial cycles is probably in the order of 30-50. One of the coldest glacial periods was at 451-425 ka BP, when the sea level dropped to $-140 \mathrm{~m}$ below the present-day level. In comparison, the next interglacial was very warm, so current calculations set the sea level $+20 \mathrm{~m}$ higher in comparison to the present-day one (ibid.). This is significant, as Google Earth images (Anonymous, 2013) of the northern Somali coast clearly show visible former beaches at many locations, at elevations of about $+18 \mathrm{~m}$. On Socotra along the entire Noged coastal plain, an abrasion terrace (several metres high) appears to be at $18-21 \mathrm{~m}$ a.s.l., while on the northern coast some pebble beaches are visible at this elevation. On both Somalia and Socotra coasts lower beaches can also be found. On the other hand, no other such clear features are at a higher position above sea level, with one exception on Somali coast south of Bargaal (at point $11^{\circ} 11^{\prime} 38^{\prime \prime} \mathrm{N}, 51^{\circ} 04^{\prime} 45^{\prime \prime} \mathrm{E}$ ), as there is probably an older beach at elevation $+26 \mathrm{~m}$ a.s.l. This supports the idea that the Somalia and Socotra coast were tectonically stabile during this period, in almost the same elevation as present. If so, it is highly probable that the same applies to the entire Socotra platform. This led to conclusion that the Somalia shelf and the Socotra Platform were periodically submerged and exposed during the Pleistocene. The last three glacial periods were very strong, resulting in a sea level decrease of about $-130 \mathrm{~m}$. Their timing is $270-260 \mathrm{ka} \mathrm{BP}, 180-130 \mathrm{ka} \mathrm{BP}$, and 35.6-11.6 ka BP. At these periods migration possibilities between the Socotra Archipelago and the African mainland increased.

The wide and deep Guardafui basin and narrow and shallow Brothers basin, were permanently flooded nevertheless, thus creating a barrier for the migration of the majority of terrestrial biota. Distances between coasts that must be crossed by terrestrial biota in various migration directions, during times of varying sea level, are presented in Tab. 1.

Table 1: Distances between coasts in best direction with minimum of sea $(\mathbf{k m})$

\begin{tabular}{|c|c|c|c|c|c|c|c|c|c|}
\hline section & $\begin{array}{c}\text { Horn of } \\
\text { Africa - } \\
\text { Abd al- } \\
\text { Kuri }\end{array}$ & $\begin{array}{c}\text { Abd } \\
\text { al- } \\
\text { Kuri }\end{array}$ & $\begin{array}{l}\text { Abd al- } \\
\text { Kuri - } \\
\text { Samhah }\end{array}$ & $\begin{array}{l}\text { Sam- } \\
\text { hah }\end{array}$ & $\begin{array}{l}\text { Sam- } \\
\text { hah - } \\
\text { Darsa }\end{array}$ & Darsa & $\begin{array}{l}\text { Darsa - } \\
\text { Socotra }\end{array}$ & $\begin{array}{l}\text { Horn of } \\
\text { Africa - } \\
\text { Socotra }\end{array}$ & $\begin{array}{c}\text { Ras Fartak } \\
\text { - Socotra }\end{array}$ \\
\hline \multirow{3}{*}{ present } & & & & & & & & 233 by air & 350 by air \\
\hline & 95 & 36 & \multicolumn{5}{|c|}{106 on sea } & $\begin{array}{c}237 \text { total } \\
201 \text { on sea }\end{array}$ & \\
\hline & 95 & 36 & 64 & 12 & 17 & 7 & 36 & $\begin{array}{c}267 \text { total } \\
212 \text { on sea }\end{array}$ & \\
\hline$-70 \mathrm{~m}$ & 81 & 53 & 22 & \multicolumn{4}{|c|}{103 on land } & 103 on sea & 332 \\
\hline$-110 \mathrm{~m}$ & 64 & 51 & 14 & \multicolumn{4}{|c|}{110 on land } & 78 on sea & 327 \\
\hline$-130 \mathrm{~m}$ & 62 & 57 & 12 & \multicolumn{4}{|c|}{102 on land } & 74 on sea & 323 \\
\hline
\end{tabular}

Migration barrier of sea between the African mainland and Socotra Isl. diminished substantially in glacial periods, with lowering of the sea level, but still remained a great barrier for terrestrial biota. At the lowest possible sea level during maximum glaciations, over $70 \mathrm{~km}$ of sea had to be crossed. On the other hand, as the abovementioned book (Brown \& Mies, 2012) and sources cited therein proved, occasional long distance movements of species across the sea is probable. A distance of about $74 \mathrm{~km}(62+12 \mathrm{~km})$ is not fatal in this view. The narrow Brothers basin led to partial separation of biota of Abd al-Kuri from other islands within the Socotra Platform, thus enabling its partly different evolution resulting in its own endemic species. 


\section{Problem of Socotra's "missing" mammals}

Mammals were present on the adjacent mainland at the time of Socotra's initial isolation, and presumably some were also present on the nascent Islands (Cheung \& De Vantier, 2006). So why are mammals on the Socotra Archipelago missing? A final conclusion has not yet been reached, but some reasons are explained by Mac Arthur and Wilson's theory of island biogeography (MacArthur \& Wilson, 1967). It is possible that those early isolated mammal populations were too small to remain viable over the long term, or perhaps the islands were not sufficiently large, and their habitats not sufficiently productive, to sustain them (Cheung \& De Vantier, 2006). The Socotra Archipelago became isolated from the mainland about $17 \mathrm{Ma} \mathrm{BP}$ (see above). If the mammal populations did not become extinct soon after this event, what was the crucial time for this? This question could be subdivided to partial ones: At what time after $17 \mathrm{Ma}$ BP was Socotra Island at its smallest? At what time were the climatic conditions, and thus availability of food for mammals, most unfavourable? As stated above, a relatively large sea transgression commenced just after $16 \mathrm{Ma} \mathrm{BP}$, and maximal flooding of the island could be supposed about 14-13 Ma BP. The position of sediments of Adawnib formation suggests the Socotra Island was partially submerged at that time, with sea waters up to $300 \mathrm{~m}$ higher than present levels. If only $200 \mathrm{~m}$ is calculated and probable topography at that time is considered, the area of the Island should be smaller by ca $1000 \mathrm{~km}^{2}$, that is ca $30 \%$, but probably more. At $14 \mathrm{Ma} \mathrm{BP}$ a great glacial expansion within the southern Hemisphere began, that later led to a decrease of the global sea level by about ca $-100 \mathrm{~m}$. (Barry \& Gan, 2011). Therefore it is probable that the deepest submergence of the Island commenced shortly after the beginning of glacial expansion. During that period monsoons increased in severity, summer ones being relatively dry as coming partly from the African mainland. This led to the drying out of the northeast coast of Africa, as well as of the Socotra Archipelago. Such conditions likely restricted the availability of food sources for herbivores and consequently for carnivores. If so, larger mammal species probably became extinct by $13 \mathrm{Ma} \mathrm{BP}$. This could explain an absence of mammal fossils, both on the surface and close to the surface layers. Terrestrial sediments from that geological period, that could potentially contain such fossil remains, are not known on the Socotra Isl. yet. Despite this, fossils could be present in sediments in paleokarstic caves and abysses from the Miocene Epoch. Fossil fragments could also be present in sediments of Adawnib Formation, which is strongly restricted to some fragments close to western and northern coasts of the Socotra Island. However, the present absence of smaller mammals remains a question.

\section{Immigration of species - possible influence of tsunami and oceanic currents}

What could enable some terrestrial species to cross the channels? About $20 \mathrm{Ma} \mathrm{BP}$ monsoons supposedly began in Asia, increasing in force about $14 \mathrm{Ma} \mathrm{BP}$ and ca 7-8 Ma BP (Prell \& Kutzbach, 1992). Present-day summer monsoons, with permanent unidirectional south-west winds attacking the Socotra Isl., cause a strong current along the Somali coast, with speeds of $4 \mathrm{~km} / \mathrm{h}$ (Shenoi, Saji \& Almeida, 1999). On 26 December 2004 a devastating earthquake hit the Sumatra coast, and the resulting tsunami devastated not only surrounding coasts and those of Sri Lanka, but to a lesser extent also flooded the Somalia coast. The energy of the tsunami was partly absorbed by the Maldives range and reefs in the central Indian Ocean; nevertheless, the Puntland coast in northern Somalia was impacted by a tsunami run-up height of $9 \mathrm{~m}$, and inundation distances up to $700 \mathrm{~m}$. In the area of Cape Ras Xaafuun the tsunami caused 300 human causalities, and destroyed shelters and houses over an extensive area (Fritz \& Okal, 2008). If the epicentre of the earthquake was situated more southerly, at central part of the Sumatra Isl., a tsunami would have almost 
uninterrupted passage to the east coast of Africa, south of the Equator. If such a tsunami was powerful enough, it could flood the low-lying coast of present-day northern Kenya at $2^{\circ} \mathrm{S}$, and flush masses of biological material to the ocean. This locality is ca $2,100 \mathrm{~km}$ in distance from Socotra Isl. and the Somali current starts here (ibid.). If such an event happened during the summer monsoon, the resulting biological debris would be transported by the sea current to the Socotra Island in about 24 days (if average speed of current 3.6 $\mathrm{km} / \mathrm{h}$ is calculated). During summer monsoon the sky is mostly covered by clouds, meliorating strong radiation. Some living organisms could potentially survive, deriving some fresh water from occasional rain. Survival would be more probable during transport from the north-east Somali coast; for instance, the journey from the Ras Xaafuun to the Socotra Isl. $(320 \mathrm{~km})$ could take only 4 days. Some lizards and seeds could survive this, being transported on rafts of floating material. In reality these periods would be even shorter, as persistent wind with speeds of $40-50 \mathrm{~km} / \mathrm{h}$ would push such island of floating material. During winter monsoons in December and January, a slower current from northeast along the south-east coast of the Arabian Peninsula, could reach the Somalia coast, with lesser probability also the coast of Socotra. If a distance ca $800 \mathrm{~km}$ is calculated (the current is oblique to Gulf axis) and speed of the current is about $2 \mathrm{~km} / \mathrm{h}$ (ibid.), the journey time of the current is about 17 days. If influence of wind is added, the duration of the sea crossing would probably be about 10 days. In winter the floating of living particles would take advantage of favourable climatic conditions with moderate temperatures.

\section{DISCUSSION}

To obtain a realistic picture of evolution of the Socotra Platform, with respect to terrestrial biota migration possibilities, is difficult due to the following factors:

A. Lack of data. Many geological papers were published about the Gulf of Aden territory, but mostly dealing with tectonic composition and the period of the rifting. Unfortunately, geological research of more recent history (after 17.6 Ma $\mathrm{BP}$ ) on the submerged part of the Socotra Platform was only basic and very little data was published (Nedham, 2002). Tectonic structure was roughly ascertained by geophysical research, but bedrock age and detailed characteristics are almost unknown or were not published sufficiently. This information is otherwise substantial for reconstruction of environmental conditions on the Platform, and thus migration possibilities.

B. Shallow waters of the Socotra platform and many former islands and scars make biological permeability reconstruction extremely difficult. The drop in sea level of about $40 \mathrm{~m}$ changes the permeability substantially. Moreover, this is very little for general geological research to record such small fluctuations. And a detailed study has yet to be implemented (2013).

What is most unclear is the fluctuating sea level on the Socotra Platform during the period 9-4 Ma BP that has significant implications for Socotra biota connections and evolution. 


\section{RÉSUMÉ}

Analysis of information led to this migration possibilities evaluation:

1. Until $43 \mathrm{Ma}$ BP an area of the Socotra Archipelago was mostly submerged in shallow tropical sea, often with coral reefs. Emergence events during the Jurassic/Cretaceous and Cretaceous/Tertiary transitions were probably of no biogeographical importance, as during following millions of years the area was flooded again. Casual flat coral islands could be the exceptions.

2. $\mathrm{Ca} 43 \mathrm{Ma} \mathrm{BP}$ a minor island probably emerged from the sea; this could have been the first continuous predecessor of present Socotra Isl.

3. At $41 \mathrm{Ma} \mathrm{BP}$ a large low and flat elevation emerged, in an area of the future Gulf of Aden. Since that some part of present-day Socotra Isl. was emerged with high probability up to present.

4. At 38-34 Ma BP some areas of eastern Socotra were strongly uplifted, namely the present Haggier Mts., and the crystalline basement was exposed on some places. The area of Haggier Mts. has been continuously emerging up to present day, with a probability close to $100 \%$.

5. Terrestrial species migration possibilities, between present Arabia and Socotra, were restricted ca $35 \mathrm{Ma} \mathrm{BP}$, as the axis of future rift was partially flooded by shallow sea. Land bridges and stepping stones were probable. Migration was also possible across the present western Gulf of Aden. With greater uncertainty the same situation was present within the Guardafui basin, separating the African mainland and the Socotra Platform.

6. At 26-20 Ma BP the majority of the Socotra Platform, and the western Socotra Isl., was submerged, thus partially separating the biota that settled there.

7. The last significant period for terrestrial biota migration, between Socotra and the Arabian Peninsula or African mainland, occurred between 20-17.6 Ma BP, during final uplift of the rifted area before its break-up. However, some shallow sea with coral reefs along the rift axis made a semi-permeable (?) barrier. The same situation probably occurred in the Guardafui basin.

8. Approximately $16 \mathrm{Ma} \mathrm{BP}$, almost the entire Socotra Platform and lowlands of Socotra were submerged for the next ca $9 \mathrm{Ma}$. It was a time of increasing isolation of islands. The Abd al-Kuri Isl. has become definitely isolated from other Islands in the Archipelago by sea.

9. Larger mammals, if present on the Socotra Archipelago, probably died out ca $13 \mathrm{Ma}$ BP. Their fossilised skeletons could be preserved in sediments in caves formed during the Miocene Epoch.

10. During the period ca 9-5 Ma BP the majority of the Socotra Platform was probably slightly uplifted; moderate uplift and tilting resulted in the lower highlands of Socotra, whilst intensive uplift formed the Haggier Mts. Migration between Socotra and Africa was moderately easier, but Guardafui basin created a barrier. Since ca 9 Ma BP the Brothers basin has separated Abd al-Kuri Isl. from other islands of the Socotra Archipelago.

11. Between 5-3 Ma BP the Socotra Platform was probably flooded again, and islands were more isolated; the distance between Arabia and Socotra became very important.

12. During the period 3-0 Ma BP part of the Socotra Platform emerged and submerged ca 30-50 times, due to glacial cycles. Time spans when the Platform was emerged 
were 5-10 times shorter than those when the Platform was submerged. Between 3-0.5 Ma BP it is probable that only higher parts of Platform were periodically emerged, with frequent islands forming stepping stones. During the last period (0.5-0.0 Ma BP) most of the Platform emerged during widespread and severe glacial periods. Nevertheless, the Guardafui and Brothers Basins persisted and created a barrier for terrestrial biota.

The future research on this field should be aimed to:

1. Ascertain the Guardafui basin evolution, as this is a crucial barrier to the Socotra Archipelago. Bedrocks composition of last 45 Ma years is the most important.

2. Constrain the timing in emerge-submerge history of the Socotra Platform. Detailed close to surface geological research of upper layers on small horsts and in Brothers basin should be conducted.

3. Study the geomorphological evolution of the Socotra Isl., the evolution of the Haggier Mts. being of most importance.

4. Search for fossil mammal skeletons in Miocene caves and bedrock layers on all islands of the Socotra Archipelago. This could help to ascertain the migration possibilities across Guardafui and Brothers basins.

\section{REFERENCES}

Anonymous, (1978). Socotra, Samhah, Darsa. Russian Military Map 1:200 000. Red Army Archive. Moscow.

Anonymous, (1999a). Nautical Charts online: Approaches to Soqutra. Retrieved December 2, 2013 from web:http://www.nauticalchartsonline.com/chart/zoom?chart=620 46.

Anonymous, (1999b). Nautical Charts online: Soqutra and Adjacent Islands. Retrieved December 2, 2013 from web: http://www.nauticalcharts online.com/chart/detail/62040Suqutra-and-Adjacent-Islands.

Anonymous, (1999c). Nautical Charts online: Raas Aantaara to Raas Binna including Abd Al-Kuri. Retrieved December 2, 2013 from web:http://www.nauticalchartsonline.com /chart/detail/62050-Raas-Aantaara-to-RaasBinna-including-Abd-Al-Kuri.

Anonymous, (2003). Geological Map of Yemen. Socotra Island, 1: 100.000. Geological Survey and Mineral Resources Board, 2003. Geological Survey Department, Aden, Yemen.

Anonymous, (2013). Google: Google Earth. Retrieved February 22, 2013, from web: http://www.google.com/earth/explore/products/

Al-Wosabi, M. \& Al-Aydrus, A., (2011, April-August). Microfacies Analysis and Depositional Environments of Tertiary Carbonate Sequences in Socotra Island, Yemen. Geological Bulletin of Turkey. 54(1-2): pp. 57-80. Retrieved December 1, 2013, from Web: http://www.jmo.org.tr/resimler/ekler/2d6daf7df19d169_ek.pdf

Al-Wosabi, M. \& Wasel, S., (2011). Lithostratigraphic subdivision of the Kuhlan Formation in Yemen. Arabian Journal of Geosciences. Nov. 2011, 4(7-8): pp. 1323-1335. Retrieved November 15, 2013, from web: http://link.springer.com/article/10.1007/s12517010-0236-9?no-access=true. DOI: 10.1007 /s12517-010-0236-9. 
As-Saruri, M.A., Sorkhabi, R. \& Baraba, R., (2010, September). Sedimentary basins of Yemen: their tectonic development and lithostratigraphic cover. Arabian Journal of Geoscience 3(4): pp. 515-527. Springer. Retrieved November 10, 2013, from web: http://www.researchgate.net/publication/225702152_Sedimentary_basins_of_Yemen_their _tectonic_development_and_lithostratigraphic_cover. DOI: 10.1007/s12517-010-0189-z.

Avigad, D. \& Gvirtzman, Z., (2009). Late Neoproterozoic rise and fall of the northern Arabian-Nubian shield: the role of lithospheric mantle delamination and subsequent thermal subsidence. Tectonophysics, 477, pp. 217-228. Retrieved November 20, 2013, from web: http://earth.huji.ac.il/ data/pics/AvigadGvirtzman.pdf. DOI:10.1016/j.tecto.2009. 04.018.

Bache, F., Leroy, S., Baurion, C., Robinet, J., Gorini, C., Lucazeau, F., Razin, P., d'Acremont, E. \& Al-Toubi, K., (2010, October). Post-rift uplift of the Dhofar margin (Gulf of Aden), Terra nova, 23, pp. 11-18. Retrieved November 3, 2013, from web: http://onlinelibrary.wiley.com/doi/10.1111/j.1365-3121.2010.00975.x/full. DOI:10.1111/ j.1365-3121.2010.00975.x, 2010.

Barry, R. \& Gan, T.Y., (2011). The global Cryosphere. Cambridge University Press. Cambridge.

Batelka, J., (2012, December). Socotra Archipelago - a lifeboat in the sea of changes: advancement in Socotran insect biodiversity survey. Acta Entomologica Musei Nationalis, 52 (supll. 2), pp. 1-26. Retrieved November 10, 2013 from web: http:// www.aemnp.eu/PDF/52_s2/52_s2_1.pdf.

Beydoun, Z.R. \& Bichan, M.R., (1970). The geology of Socotra Island, Gulf of Aden. Q. J. Geol. Soc. Lond. 125, pp. 413-446.

Birse, A.C.R., Bott, W.F., Morrison, J. \& Samuel, M.A., (1997). The Mesozoic and Early Tertiary tectonic evolution of the Socotra area, eastern Gulf of Aden, Yemen. Marine and Petroleum Geology 14/6, pp. 675-684.

Blakey, R., (2011, March). Paleography. Retrieved October 4, 2013, from web: http://jan.ucc.nau.edu/ rcb7/paleogeographic.html.

Bosworth, W., Huchon, P. \& McClay, K., (2005). The Red Sea and Gulf of Aden basins. Journal of African Earth Sciences 43, pp. 334-378.

Bott, W.R., Richardson, S.M., Harbury, N.A., Johns, C., Scott, D., Samuel, M.A., Cranmer, F.S., Smith, B.A. \& Hollard, B.D., (1994). Remote Socotra and Ancillary Islands: recent field investigations of Paleozoic and Mesozoic outcrops and their relationship to speculative petroleum systems. Geo'94: The Middle East Petroleum Science - Selected Middle East Papers from the Middle East Geoscience Conf. 1, pp. 213-233.

Brown, G. \& Mies, B., (2012). Vegetation Ecology of Socotra. Plant and Vegetation 7. Heidelberg, Springer. Germany.

Cheung, C. \& De Vantier, L., (2006). Socotra - A natural history of the islands and their people. In: Van Damme, K. Science, (Ed.) Odyssey Books and Guides, Airphoto International Ltd., Hong Kong.

Culek, M., Král, K., Habrová, H., Adolt, R., Pavliš, J. \& Maděra, P., (2006). Socotra's annual weather pattern. In Cheung, C. \& De Vantier, L., 2006. Socotra - A natural history of the islands and their people. Box 2.4. (pp. 42-45). Odyssey Books and Guides, Airphoto International Ltd., Hong Kong. 
d'Acremont, E., Leroy, S., Beslier, M.-O., Bellahsen, N., Fournier, M., Robin, C., Maia, M. $\&$ Gente, P., (2005). Structure and evolution of the eastern Gulf of Aden conjugate margins from seismic reflection data. Geophys. J. Int. (2005) 160, pp. 869-890. Retrieved November 20, 2013 from web:http://marc.fournier.free.free.fr/publicationsd_Acremont_et_al_ GJI_2005.pdf. DOI: 10.111/j.1365246X.2005.025 24.x.

d'Acremont, E., Leroy, S., Maia, M., Gente, P. \& Autin, J., (2010). Volcanism, jump and propagation on the Sheba ridge, eastern Gulf of Aden: Segmentation evolution and implications for oceanic accretion processes, Geophys. J. Int., 180 (2), pp. 535-551. Retrieved November 1, 2013, from web:http://onlinelibrary.wiley.com/doi/10.1111/j.1365246X.2009.04448.x.DOI:10.1111/J.1365-1246x.2009.04448.X.

Denele, Y., Leroy, S., Pelleter, E., Pik, R., Talbot, J.Y. \& Khanbari, K., (2012). The Cryogenian arc formation and successive high-K calc-alkaline plutons of Socotra Island (Yemen). Arab. J. Geosci. 5(5), pp. 903-924.

Fleitmann, D., Matter, A., Burns, S.J., Al-Subary, A. \& Al-Aowah, M.A., (2004). Geology and Quaternary climate history of Socotra. In Krupp, F. (ed.). Fauna of Arabia. Socotra Archipelago, vol. 20, Libri, Basel.

Fournier, M. et 14 authors, (2010). Arabia-Somalia plate kinematics, evolution of the AdenOwen-Carlsberg triple junction and opening of the Gulf of Aden. Journal of Geophysical Research 115 (pp. 1-24). Retrieved November 17, 2013, from web: http://marc.fournier. free.free.fr/publications/Fournier_et_al_JGR_2010.pdf.DOI:10.1029/2008JB006257.

Fournier, M., Huchon, P., Khanbari, K. \& Leroy, S., (2011, April). Segmentation and along-strike asymmetry of the passive margin in Socotra, eastern Gulf of Aden: Are they controlled by detachment faults? Geochemistry Geophysics Geosystem 8 (2007) Q03007. Retrieved November 1, 2013, from web: http://marc.fournier. free.free.fr/publications/ Fournier_et_al_G3_2007.pdf. DOI: 10.1029/2006GC001526

Fritz, H.M. \& Okal, E.A., (2008). Socotra Island, Yemen: field survey of the 2004 Indian Ocean tsunami. Nat. Hazards (2008) 46:107-117. Retrieved November 2, 2013, from web: http://link.springer.com/article/10.1007/s11069-007-9185-3. DOI 10.1007/s110 69-0079185-3.

Goudie, A.S. (ed.), (2006a). Denudation. In Encyclopedia of Geomorphology (Vol. 1). Int. Ass. of Geomorphy (pp. 240-244). Routledge Ltd., London, New York: Encyclopedia of Geomorphology.

Goudie, A.S. (ed.), (2006b). Escarpment. In Encyclopedia of Geomorphology (Vol. 1). Int. Ass. of Geomorph (pp. 337-340). Routledge Ltd., London, New York: Encyclopedia of Geomorphology.

Haq, B.U., Hardenbol, J. \& Vail, P.R., (1987). Chronology of Fluctuating sea levels since the Triassic (250 million years ago to present). Science 235: pp. 1156-1167.

Lambeck, K., Purcell, A., Fleming, F.C., Vita-Finzi, C., Alsharekh, A.M. \& Bailey, G.N., (2011). Sea level and shoreline reconstructions for the Red Sea: isostatic and tectonic considerations and implications for hominine migration out of Africa. Quaternary science reviews 30 (2011), pp. 3542-3574. Elsevier. Retrieved December 1, 2013, from web: http://www.nhm.ac.uk/ natureplus /blogs/science-news/2012/04.

Leroy, S. et 27 authors, (2013). From rifting to oceanic spreading in the Gulf of Aden: A synthesis. [Abstract]. In Al-Hosani K., Roure F., Ellison R. \& Lokier, S. (eds.). Lithosphere Dynamics and Sedimentary Basins: The Arabian Plate and Analogues (pp. 385-427). Berlin, Heidelberg: Springer-Verlag. Retrieved November 3, 2013, from web: 
http://link.springer.com/article/10.1007\%2Fs12517-011-0475-4. DOI: 10.10 07/978-3-64230609-9_20.

Kalvoda, J., (2005). Morfostrukturní vývoj reliéfu lokality GOPE v Ondřejovské vrchovině. Geomorfologický sbornik, 4, (pp. 33-36), České Budějovice. Retrieved November 4, 2013, from web: http://www.kge.zcu.cz/geomorf/sbornik/sbornik_05/kalvoda_gope.pdf.

MacAtrhur, R.H. \& Wilson, E.O., (1967). The Theory of Island Biogeography. Princeton University Press, New Jersey, USA.

Mazzini, I. \& Sardella, R., (2004, September). Notes on the freshwater ostracods (Arthropoda: Crustacea) and on the Quaternary deposits of Socotra. Fauna of Arabia 20, 181191. Retrieved December 3, 2013, from web: https://www.academia.edu/915663/Notes on_the_freshwater_ostracods_Arthropoda_Crustacea_and_on_the_Quaternary_deposits_of_Socotra.

Mies, B., (2001). Flora und Vegetationsokologie der Insel Soqotra. Essener Okologische Schriften 15. Westarp Wissenschaften, Essen, Germany.

Miller, A.G. \& Morris, M., (2004). Ethnoflora of the Socotra Archipelago. Royal Botanic Garden, Edinburgh.

Nedham, M.D.A., (2002). A new look to the Yemeni geology based on new solutions to the most chaotic Yemeni geological problems. Unpublished doctoral dissertation, Jilin University, Changchun, China. Retrieved November 23, 2013, from web: http://www. slideshare.net/DrEngMoha mmedDarsi/a-new-look-to-the-yemeni-geology-based-on-newsolutions-to-the-most-chaotic-yemeni-geological-problems.

Olson, D.M., Dinerstein, E., Wikramanayake, E.D. and other 14 co authors, (2001). Terrestrial Ecoregions of the World: A New Map of Life on Earth. BioScience, vol. 51/11, pp. 933-938.

Open Street Map, (2014). Open Street Map, Retrieved March 18, 2014, from web: http://www.openstreet map.org/\#map=6/14.902/51.218\&layers=T.

Pik, R., Bellahsen, N., Leroy, S., Denèle, Y., Razin, P., Abdulhakim, A. \& Khanbari, K., (2013, August). Structural control of basement denudation during rifting revealed by lowtemperature (U-Th-Sm)/He thermochronology of the Socotra Island basement - Southern Gulf of Aden margin. Tectonophysics 607 (2013), pp. 17-31. Retrieved December 3, 2013, from ScienceDirect on web:http://www.sciencedirect.com/science/article/pii/S0040195 113004794,http://dx.doi.org/10. 1016/j.tecto.2013.07.038.

Prell, W.L. \& Kutzbach, J.E., (1992). Sensitivity of the Indian monsoon to forcing parameters and implications for its evolution. Nature, 360, pp. 647-651. Retrieved November 10, 2013, from web: http://www.nature.com/nature/journal/v360/ n6405/abs/360647a0. html. DOI: 10.1038/360647a0.

Razin, P., Robin, C., Serra, K.J., Leroy, S., Bellahsen, N. \& Khanbari, K., (2009). Cenozoic evolution of the Socotra Island: opening of the Gulf of Aden [Abstract]. In: American Geophysical Union, Fall Meeting 2009, abstract \#T31C-1840. Retrieved December 3, 2013, from web:http://adsabs.harvard.edu/abs/2009AGUFM. T31C1840R.

Samuel, M.A., Harbury, N.A., Bott, W.F. \& Thabet, A., (1997). Fields observation from Socotran platform: their interpretation and correlation to Southern Oman. Mar. Pet. Geol. 14(6): pp. 661-673.

Scholte, P. \& De Geest, P., (2010). The climate of Socotra Island (Yemen): A firsttimeassessment of the timingof the monsoon wind reversal and its influence on 
precipitation andvegetation patterns. Journal of Arid Environments (2010). DOI:10.1016/j.jaridenv. 2010.05.017

Shenoi, S.S.C., Saji, P.K. \& Almeida, A.M., (1999, November). Near-surface circulation and kinetic energy in the tropical Indian Ocean derived from Lagrangian drifters. Journal of Marine Research, 57(6): 885-907(23). Retrieved December 1, 2013, from web: http://www. ingentaconnect.com/content/jmr/jmr/1999/00000057/00000006/art 00003. DOI: $10.1357 /$ 002224099321514088.

Takhtajan, A.L., Crovello, Th.J. \& Cronquist, A., (1986). Floristic Regions of the World. University of California Press, USA.

Udvardy, M.D.F., (1975). A Classification of the Biogeographical provinces of the World. IUCN occasional paper No. 18. UNESCO. Morges. Switzerland.

Wranik, W., (1999). Soqotra. Mensch und Natur. Jemen Studien 14. Wiesbaden. 